\title{
Hydrochemical characterization and vulnerability assessment of unconfined groundwater systems in Ore area, Southwestern Nigeria
}

\author{
Temitayo Dayo Akinfaderin ${ }^{1}$ - Yinusa Ayodele Asiwaju-Bello ${ }^{1}$ Miriam Tolulope Ogunsuyi ${ }^{2}$
}

(c) Springer Nature Switzerland AG 2019

\begin{abstract}
The inhabitants of Ore and its environs, Southwestern Nigeria, rely exclusively on groundwater for their domestic, industrial and irrigation purposes such that there is the need to identify and subject the recharge and discharge areas for pollution potential integrity assessment. A total of 144 dug wells were selected for the study. Topography, water table levels and hydrochemical trend methods were employed to identify twelve recharge and eighteen discharge areas. Wells in each of the areas were selected and subjected to hydrogeochemical tests to determine their hydrochemical facies types. Results showed that concentrations of cations and anions are in the order of $\mathrm{Ca}^{2+}>\mathrm{Na}^{+}>\mathrm{Mg}^{2+}>\mathrm{K}^{+}$and $\mathrm{HCO}_{3}{ }^{-}>\mathrm{Cl}^{-}>\mathrm{SO}_{4}{ }^{2-}>\mathrm{NO}_{3}{ }^{-}$, respectively. The dominant hydrochemical facies is $\mathrm{Ca}-\mathrm{HCO}_{3}$ type. These results were integrated with DRASTIC parameters to determine their pollution potentials. The results showed that both the recharge and discharge areas have low pollution potential based on their DRASTIC index values. Water quality indices result of Ore groundwater fall within good to excellent/very good categories with $31.43 \%$ and $68.57 \%$, respectively. This study indicated that groundwater sourced from both recharge and discharge areas is safe for domestic and agricultural purposes and that the groundwater is generally less vulnerable to pollution.
\end{abstract}

Keywords DRASTIC · Vulnerability · Groundwater · Pollution · Hydrogeochemical · Trilinear · WQI

\section{Introduction}

Groundwater is the most important natural resources that constitute part of the global freshwater system. It occurs beneath the water table in soils and geologic formations that are fully saturated [8]. It is estimated that about onethird of the world's population use groundwater for drinking purpose [12]. It is also an indispensable drinking water resource in developing cities, especially in places where no public water supply exists because of inadequate infrastructures or poor economic situation. Understanding the patterns and rate of groundwater flow is essential to investigate the migration of contaminant in the flow system. Recharge areas serve to replenish the supplies, but also allow for introduction of contaminants into the uppermost unconfined aquifers. Artificial recharge may result from deliberate or inadvertent human activity, such as direct injection of water into the subsurface or irrigation. Because all water supply networks leak, there is thus potential for recharge from storm sewers and drains.

Discharge areas are groundwater extraction points. Designation of recharge and discharge areas in a drainage basin is reliant upon the direction of groundwater flow within the aquifer. In recharge areas, flow of groundwater is directed away from the water table surface, while in discharge areas, the flow is directed toward the water table surface [8]. The goal of this study is to categorize the recharge and discharge areas in Ore area and assess their pollution potentials using DRASTIC approach. DRASTIC system [3] was developed by United State Environmental

$\triangle$ Temitayo Dayo Akinfaderin, temitayoakinfaderin@yahoo.ca | ${ }^{1}$ Applied Geology Department, The Federal University of Technology, Akure, PMB 704, Akure, Ondo State, Nigeria. ${ }^{2}$ Marine Science and Technology Department, The Federal University of Technology, Akure, PMB 704, Akure, Ondo State, Nigeria. 
Protection Agency and has been widely used in discriminating areas where groundwater supplies are most susceptible to contamination. Various researchers have used the DRASTIC method successfully in different parts of the world $[2,4-6,10,19,20]$.

\subsection{Drainage, climate, vegetation, topography and geological setting of the study area}

Ore is located in Odigbo local government area of Ondo state, Southwestern Nigeria. Geographically, it is located within latitudes $6^{\circ} 43^{\prime} 0^{\prime \prime} \mathrm{N}$ and $6^{\circ} 46^{\prime} 0^{\prime \prime} \mathrm{N}$ and longitudes $4^{\circ} 52^{\prime} 0^{\prime \prime} \mathrm{E}$ and $4^{\circ} 56^{\prime} 0^{\prime \prime} \mathrm{E}$ (Fig. 1). Ore and its environs have an area of about $48 \mathrm{~km}^{2}$ and a population of over 230,351 [11]. Groundwater is the main source of water for domestic, industrial and agricultural purposes by the inhabitants of the area. Groundwater recharge in the area is mainly through infiltration of rainwater. Secondary recharge occurs by influent from rivers and their tributaries. Discharges of groundwater occur through seepages, springs, well water abstraction and' flow into rivers and streams. The area is drained in the northwestern part by Ominla River. The area exhibits a typical humid tropical climate with two distinct seasons, the wet and dry seasons. The wet season spans between April and October, while the dry season period is from November to March. The main rain-bearing system affecting the area is embedded in the easterly wind current. The average annual rainfall is $1200 \mathrm{~mm}$ [14] with a mean annual maximum temperature of $32{ }^{\circ} \mathrm{C}$ around February and mean minimum of $21^{\circ} \mathrm{C}$ around August. Vegetation in the study area is of regrowth rainforest type [7]. The topography of the area is comparatively flat with heights varying from $64.5 \mathrm{~m}$ to $106.04 \mathrm{~m}$ above mean sea level. The study area lies within the crystalline basement complex rock terrain of southwestern Nigeria [16]. The dominant rock type in the area is Migmatite gneiss. This rock is unsuitable for accumulation of groundwater unless it is weathered, fractured and/or jointed [1].

\section{Methodology}

\subsection{Water level measurement}

Water level indicator was used to measure level of water in each of the 144 hand-dug wells selected for study. The data obtained were used to generate the water table distribution map for the area. The local groundwater flow vectors were deduced from this map using SURFER software package, and these flow vectors were used to identify recharge and discharge zones in the area.

\subsection{Chemical and physicochemical analyses}

144 hand-dug wells were put under study out of which 44 were carefully selected for water sampling for chemical

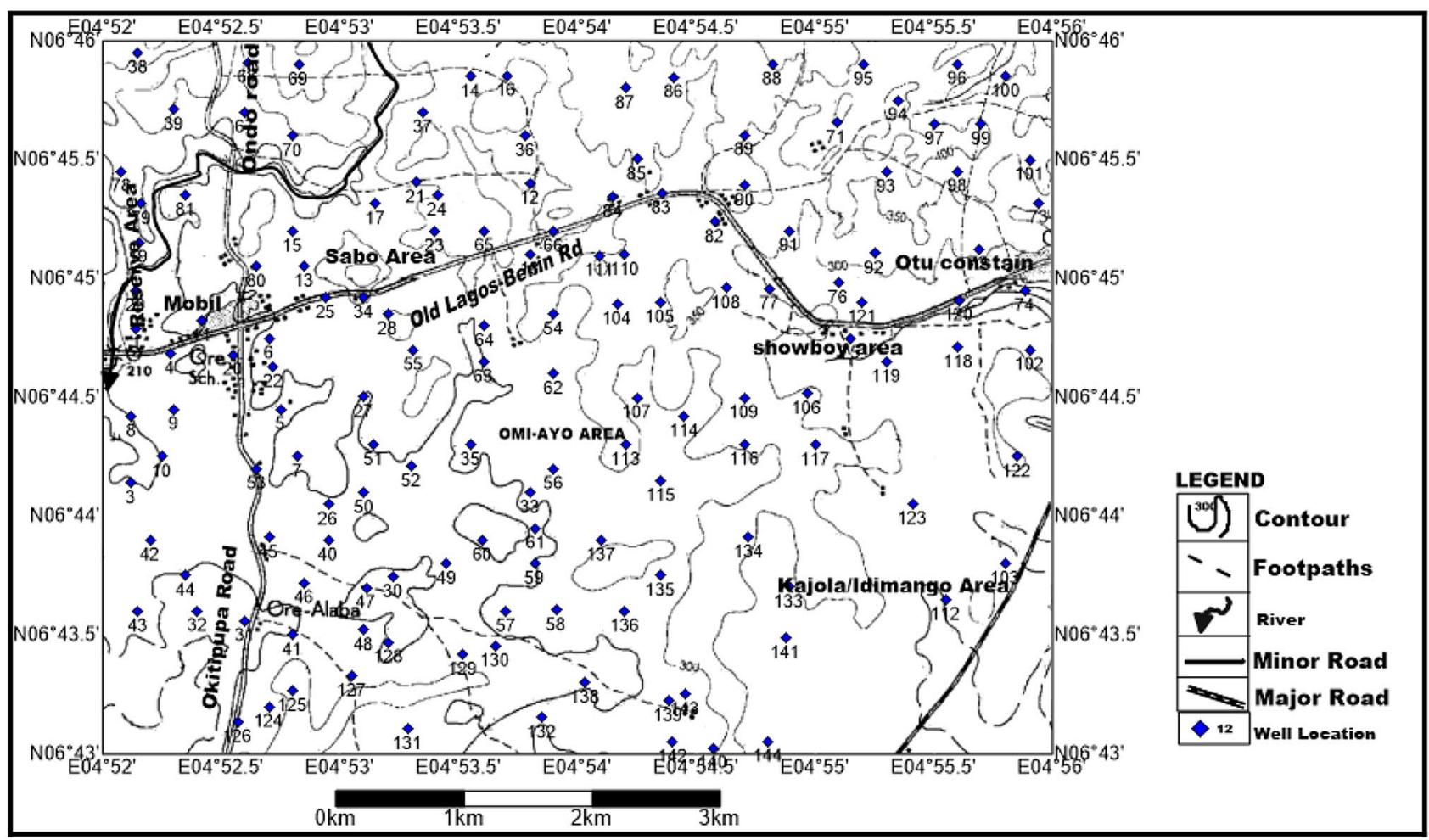

Fig. 1 Topographical map of the study area showing the sampling points 
analyses. Parameters like temperature, EC, TDS and $\mathrm{pH}$ of the water samples were measured in situ using EC/Ph/TDS temperature meter. In the laboratory, flame photometer was used to determine the dissolved concentrations of calcium, magnesium, sodium and potassium, while turbidimetric technique using spectrophotometer was employed in the determination of dissolved concentrations of bicarbonate, chloride, nitrate and sulfate concentrations. Chromium, manganese, zinc, copper, lead and iron concentrations were determined using AA320N Atomic Absorption Spectrophotometer.

\subsection{DRASTIC method}

DRASTIC was used to evaluate the relative vulnerability of areas to groundwater contamination by focusing on hydrogeologic factors that influence pollution potential [3]. The standard hydrogeologic factors normally used are depth to water, net recharge, aquifer media, soil media, topography, impact of the vadose zone and hydraulic conductivity that make up the acronym DRASTIC. In practice, a combination of ratings and weights are assigned to these factors based on how significant they influence pollution potential. In line with standard practice [3], each DRASTIC factor was assigned a DRASTIC weight ranging from 1 to 5 (Table 1). Each DRASTIC factor was further assigned a rating, typically from 1 to 10 based on a range of information within the parameter. Higher ratings and weights indicated higher risk of vulnerability. The values of the ratings and weights for each parameter are plugged into an equation to determine the pollution potential known as the DRASTIC Index. The standard equation [3] for the DRASTIC Index is:

$$
\begin{aligned}
& D_{R} D_{W}+R_{R} R_{W}+A_{R} A_{W}+S_{R} S_{W}+T_{R} T_{W}+I_{R} I_{W}+C_{R} C_{W} \\
& \quad=\text { Pollution Potential }
\end{aligned}
$$

where $R$ rating and $W$ weight.

The DRASTIC Index is the computed value that makes it possible to identify areas more susceptible to groundwater contamination. The higher the DRASTIC index, the higher the susceptibility.

Table 1 Drastic weight parameters [3]

\begin{tabular}{ll}
\hline Hydrogeological factors & Weight \\
\hline Depth to groundwater & 5 \\
Recharge (net) & 4 \\
Aquifer media & 3 \\
Soil media & 2 \\
Topography & 1 \\
Impact to vadose zone & 5 \\
Conductivity (hydraulic conductivity) & 3 \\
\hline
\end{tabular}

\subsection{Depth to water}

The depth to water as a hydrogeological factor refers to the actual depth or distance from the ground surface to the water table [3]. It has been of great importance because it determines the thickness of material that a contaminant would have to pass through to reach the aquifer, and it may help to determine the amount of time during which the surrounding media are maintained.

Generally, the thicker the material between the surface and the water table, the higher the chance of contaminant breaking down before it can affect the aquifer. This hydrogeological parameter ranges from shallow to deep. Shallow water table has been adjudged to favor well contamination from several natural and anthropogenic activities such as runoff, infiltration and sewage leakages.

\subsection{Net recharge}

Net recharge is the amount of water (largely precipitation in millimeters) per unit area of land which infiltrates the ground surface and thereby reaches the aquifer and contributes on an annual basis [3]. Net recharge can be calculated as:

Net Recharge $=$ Precipitation-Evaporation-Run Off

But for this study, the method of [9] was employed in the calculation of net recharge.

$R_{r}=K(P-X)$

where $R_{r}$ is the net recharge, $K$ is constant, $P$ is the precipitation and $X$ is the number of point rainfall. This specific empirical formula was used for the study area.

$R_{r}=0.25(P-3)$;

This recharge water is thus available to transport a contaminant vertically to the water table and horizontally within the aquifer.

\subsection{Aquifer media}

This media refers to the bedrock character that serves as the aquifer either consolidated or unconsolidated medium [3]. The media of the rock affects the flow of water through the rock which also affects the rate and direction that a contaminant flows.

\subsection{Soil media}

Soil media refers to the portion of the earth located between the surface and the uppermost bedrock. This area contains significant biologic activity and organic material 
at the surface. The type and size of the soil media directly affect the rate of infiltration of pollutants [3].

\subsection{Topography}

Topography is the variability of the slope, or gradient of the ground surface. Slope affects the type and amount of soil at the surface of the land as well as the rate and quality of runoff. Basement terrain like the study area is usually characterized by undulating and rugged topography, thereby facilitating high runoff events [13]. These runoff events have been found to be responsible for the contamination of several basement aquifers. A contaminant introduced on a steep slope has less chance of infiltrating into the surface and would likely flow downward leaving concentrated pollutants at the base of the slope near a groundwater source. Slope is also used to determine gradient and flow of the water table since the water table is similarly influenced by the contour of the surface [3].

\subsection{Impact of the vadose zone}

Vadose zone is the unsaturated zone above the water table with weight of 5 [3]. The impact of pollution on the vadose zone is measured based on the thickness, porosity and permeability of all material within the zone. In practice, ratings are assigned per influence of the least impervious material, taking into account all types of material from the water table toward the surface.

\subsection{Hydraulic conductivity}

Hydraulic conductivity refers to the rate at which the aquifer materials transmit water [3]. The rate is affected by the material, porosity and gradient of the aquifer. It is important because it determines the rate of contaminant movement through the aquifer from the point of contact. Higher rates represent higher susceptibility to contamination [3]. Hydraulic conductivity classes were obtained from the one-dimensional flow vector values generated with SURFER while using kriging method to interpolate hydraulic heads using the formula.

$V=0.002025 * x+0.099586$

where $x$ is the length of flow path in centimeters $(\mathrm{cm})$ and $V$ is the flow velocity.

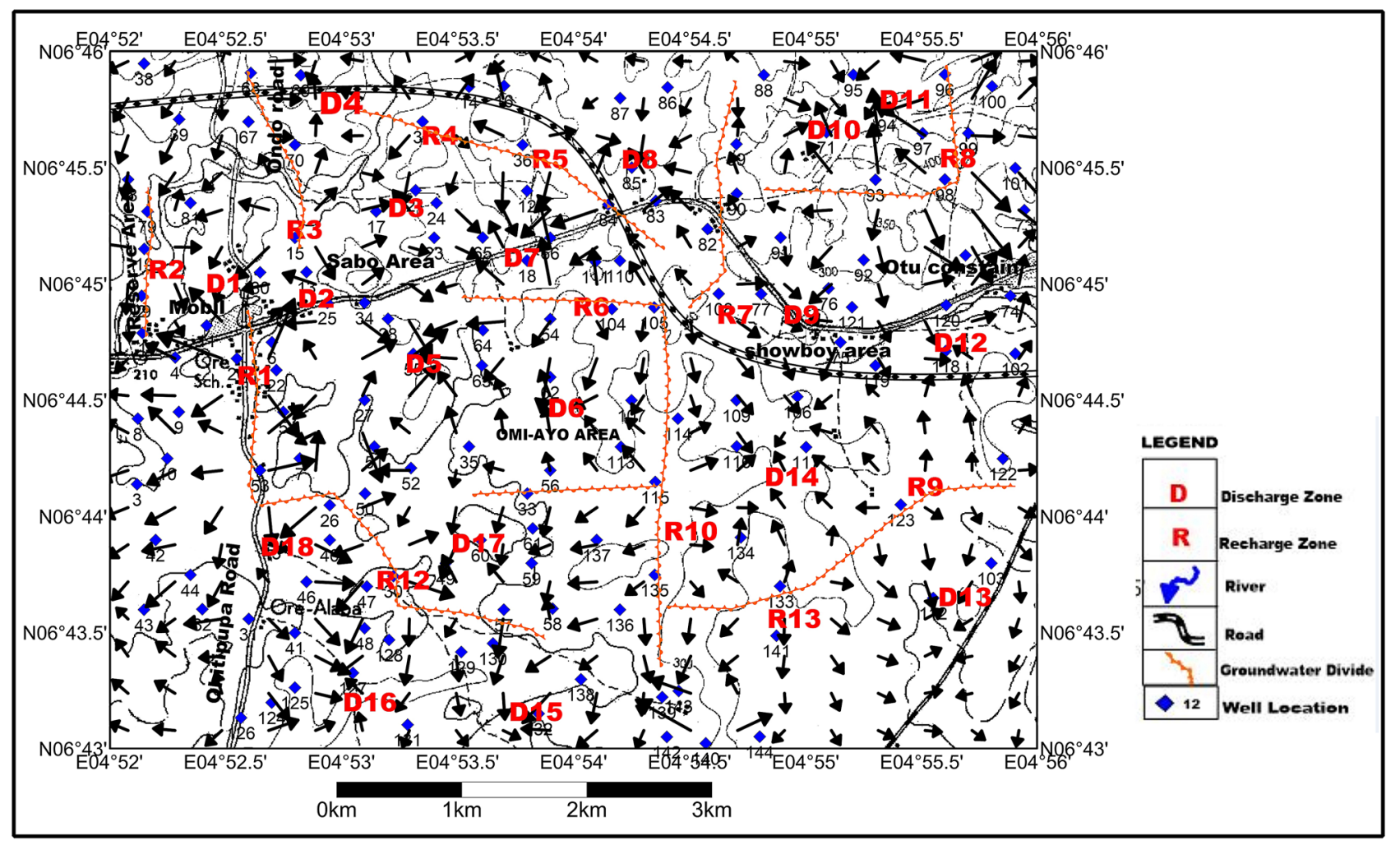

Fig. 2 Groundwater table heads distribution map showing flow vectors, recharge $(R)$ and discharge $(D)$ areas 


\section{Results and discussion}

The water table head and flow vector distribution map generated for the area are presented in Fig. 2. Trilinear piper diagram plots of the chemical concentrations of the dissolved ions are presented in Figs. 3 and 4. Summary of calculated values of DRASTIC index for the recharge and discharge areas are presented on Tables 2 and 3, while the groundwater vulnerability map generated for the study area is shown in Fig. 5.

\subsection{Groundwater recharge and discharge zones}

As shown in Fig. 2, twelve (12) groundwater recharge zones and eighteen (18) discharge zones were established within the study area. In Fig. 2, the recharge areas are designated as R1-R12, while the discharge areas are designated as D1-D18.

The distribution of these recharge and discharge areas was not controlled by the underlying geology as they were randomly located within the study area. Anthropogenic forces are believed to be the prevailing source of control.

\subsection{Water quality and hydrogeochemistry}

Quality of the groundwater was evaluated in each of the identified recharge and discharge areas. The chemical quality of the water samples around these areas was found to be within the acceptable limits of the World Health Organization (WHO) standards for drinking, domestic and irrigation purposes. The relative concentrations of cations and anions in the water samples are in the order of $\mathrm{Ca}^{2+}>\mathrm{Na}^{+}>\mathrm{Mg}^{2+}>\mathrm{K}^{+}$and $\mathrm{HCO}_{3}{ }^{-}>\mathrm{Cl}^{-}>\mathrm{SO}_{4}{ }^{2-}>\mathrm{NO}_{3}{ }^{-}$, respectively.

From the trilinear plots (Figs. 3 and 4), the $\mathrm{Ca}-\mathrm{HCO}_{3}$ hydrochemical facies type dominated the area. The water quality indices for the samples were calculated using the [17] approach. Water quality parameters such as $\mathrm{pH}, \mathrm{EC}$, TDS, $\mathrm{Ca}, \mathrm{Mg}, \mathrm{Na}, \mathrm{K}, \mathrm{HCO}_{3}, \mathrm{Cl}$ and $\mathrm{SO}_{4}$ are considered. As the preliminary step of WQI calculation, weights $\left(A_{w i}\right)$ are

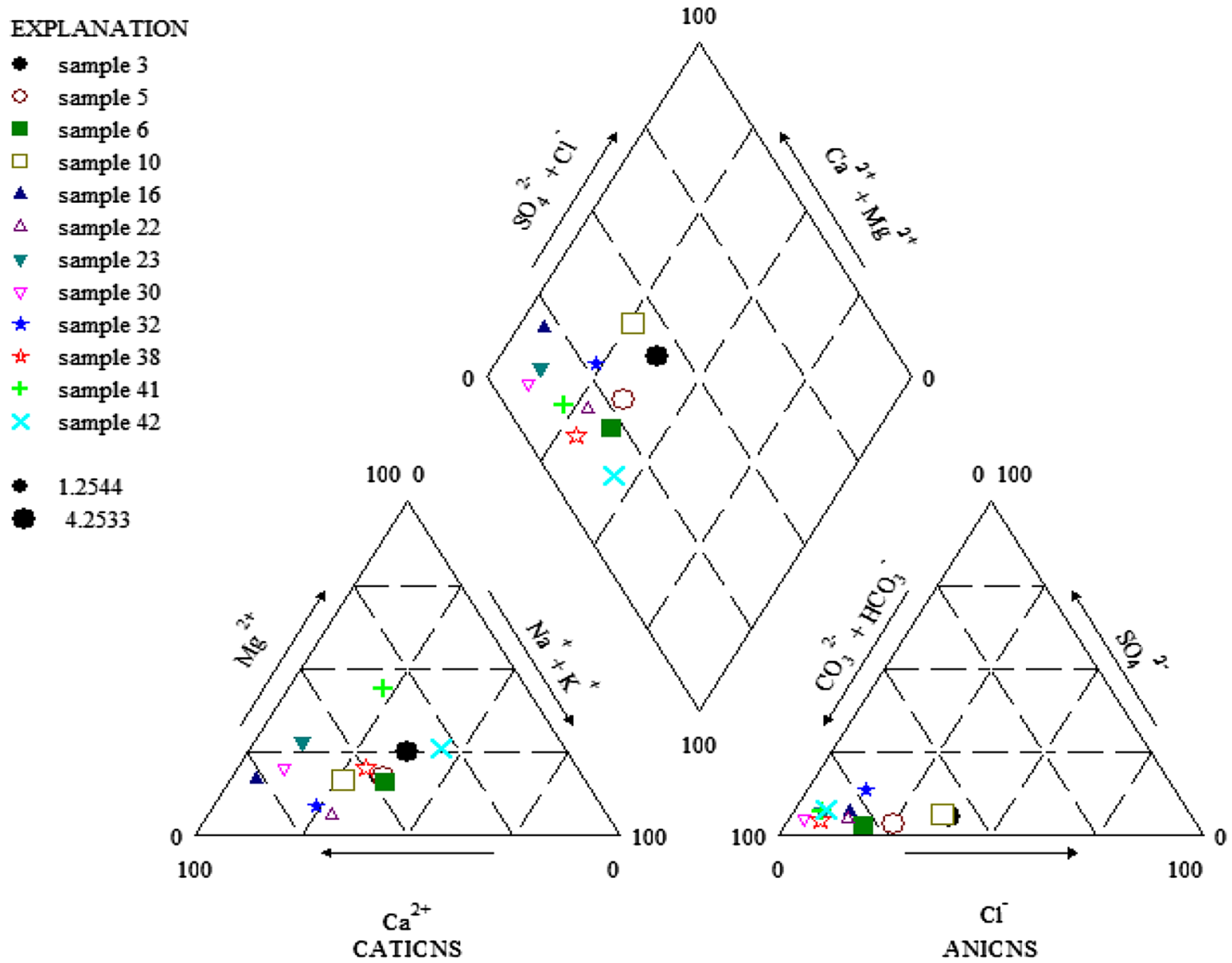

Fig. 3 Piper diagram plots of dissolved ions for recharge areas 


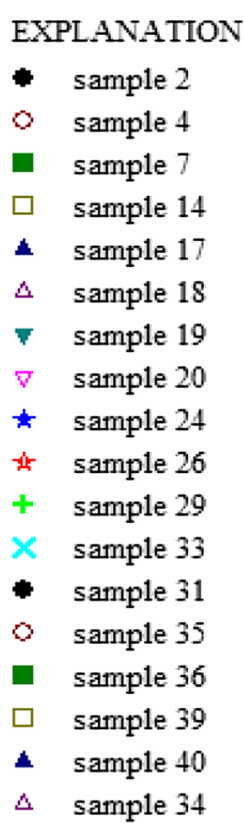

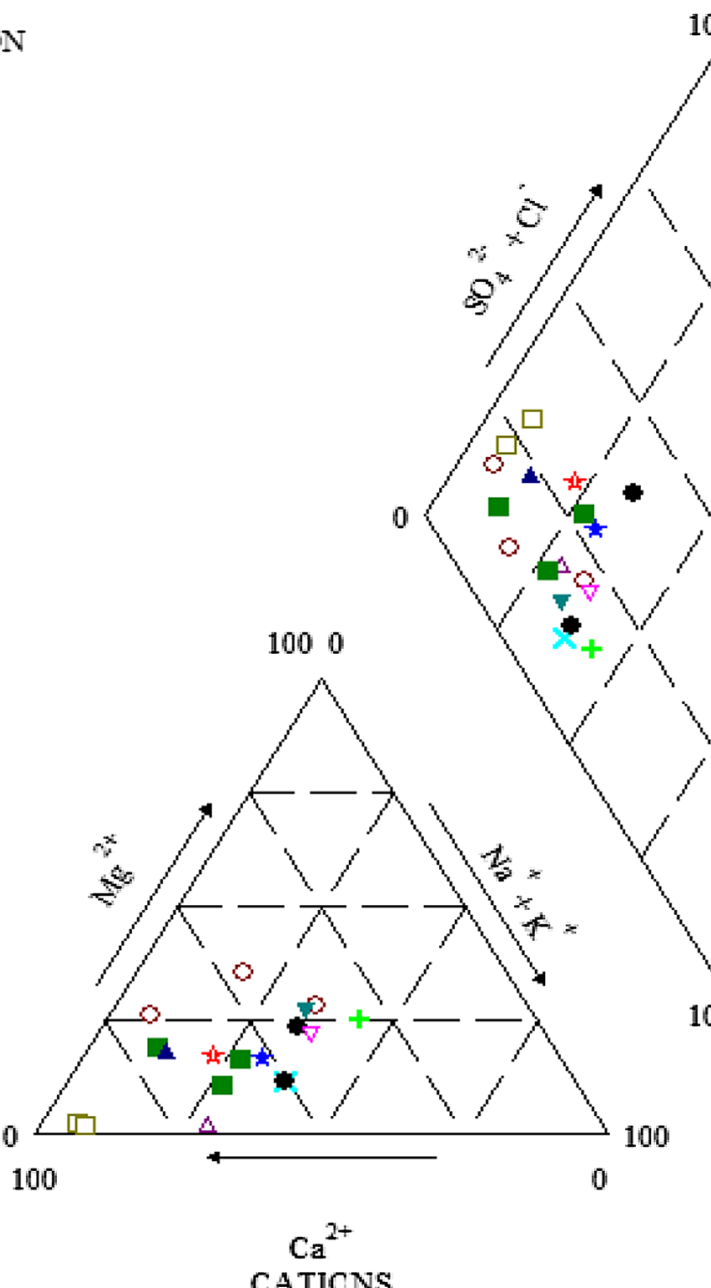

CATICNS

\section{0}

今
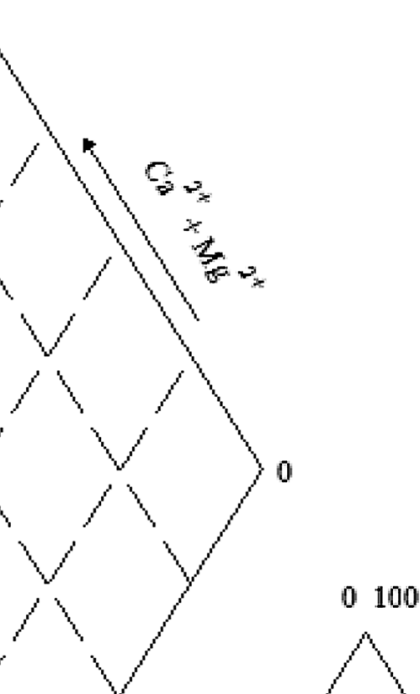

100

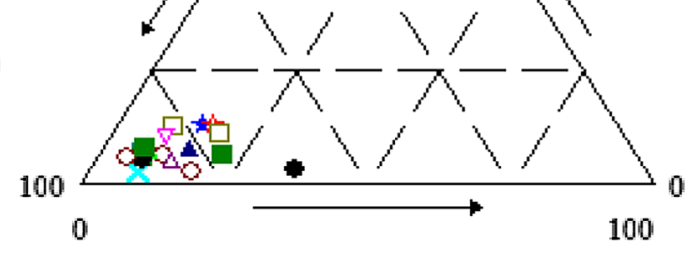

$\mathrm{Cl}^{-}$

ANICNS

Fig. 4 Piper diagram plots of dissolved ions for discharge areas

Table 2 Calculated DRASTIC index (DI) and its qualitative risk category (QRC) for the recharge areas

\begin{tabular}{lllllllllllll}
\hline Well\# & Lon004 $^{\circ} \mathrm{E}$ & Lat06 $^{\circ} \mathrm{N}$ & $\mathrm{D}$ & $\mathrm{R}$ & $\mathrm{A}$ & $\mathrm{S}$ & $\mathrm{T}$ & $\mathrm{I}$ & $\mathrm{C}$ & $\mathrm{DI}$ & $\mathrm{QRC}$ & $\mathrm{RA \#}$ \\
\hline 3 & $52.821^{\prime}$ & $44.251^{\prime}$ & 45 & 4 & 12 & 10 & 10 & 15 & 6 & 96 & Low & $\mathrm{R} 1$ \\
23 & $52.164^{\prime}$ & $45.314^{\prime}$ & 45 & 4 & 12 & 4 & 9 & 15 & 6 & 89 & Low & R2 \\
5 & $52.8^{\prime}$ & $45.2^{\prime}$ & 35 & 4 & 12 & 4 & 9 & 15 & 6 & 79 & Low & R3 \\
6 & $53.701^{\prime}$ & $44.75^{\prime}$ & 35 & 4 & 12 & 4 & 9 & 15 & 12 & 79 & Low & R4 \\
16 & $53.701^{\prime}$ & $45.855^{\prime}$ & 35 & 4 & 12 & 6 & 10 & 15 & 6 & 82 & Low & R5 \\
32 & $54.166^{\prime}$ & $44.894^{\prime}$ & 35 & 4 & 12 & 10 & 9 & 15 & 6 & 85 & Low & R6 \\
22 & $54.809^{\prime}$ & $44.958^{\prime}$ & 45 & 4 & 12 & 10 & 9 & 15 & 6 & 95 & Low & R7 \\
30 & $55.804^{\prime}$ & $45.852^{\prime}$ & 35 & 4 & 12 & 6 & 9 & 15 & 6 & 81 & Low & R8 \\
38 & $55.41^{\prime}$ & $44.052^{\prime}$ & 35 & 4 & 12 & 10 & 10 & 15 & 6 & 86 & Low & R9 \\
42 & $54.35^{\prime}$ & $43.75^{\prime}$ & 45 & 4 & 12 & 10 & 10 & 15 & 6 & 96 & Low & R10 \\
10 & $53.221^{\prime}$ & $43.745^{\prime}$ & 45 & 4 & 12 & 10 & 10 & 15 & 12 & 96 & Low & R11 \\
41 & $54.89^{\prime}$ & $43.701^{\prime}$ & 45 & 4 & 12 & 10 & 9 & 15 & 6 & 95 & Low & R12 \\
\hline
\end{tabular}


Table 3 Calculated DRASTIC index (DI) and its qualitative risk category $(\mathrm{QRC})$ for the discharge areas

\begin{tabular}{lllllllrlrlll}
\hline Well\# & Lon004 $^{\circ} \mathrm{E}$ & Lat06 $^{\circ} \mathrm{N}$ & $\mathrm{D}$ & $\mathrm{R}$ & $\mathrm{A}$ & $\mathrm{S}$ & \multicolumn{1}{c}{$\mathrm{T}$} & $\mathrm{I}$ & $\mathrm{C}$ & $\mathrm{DI}$ & $\mathrm{QRC}$ & $\mathrm{DA \#}$ \\
\hline 4 & $52.284^{\prime}$ & $44.685^{\prime}$ & 45 & 4 & 12 & 4 & 10 & 15 & 6 & 96 & low & D1 \\
2 & $52.701^{\prime}$ & $44.75^{\prime}$ & 35 & 4 & 12 & 4 & 9 & 15 & 12 & 79 & Low & D2 \\
7 & $53.329^{\prime}$ & $45.405^{\prime}$ & 35 & 4 & 12 & 6 & 10 & 15 & 6 & 82 & Low & D3 \\
20 & $52.6^{\prime}$ & $45.7^{\prime}$ & 35 & 4 & 12 & 6 & 9 & 15 & 6 & 81 & Low & D4 \\
18 & $53.61^{\prime}$ & $44.802^{\prime}$ & 35 & 4 & 12 & 10 & 9 & 15 & 6 & 85 & Low & D5 \\
33 & $54.204^{\prime}$ & $44.301^{\prime}$ & 45 & 4 & 12 & 10 & 10 & 15 & 6 & 96 & Low & D6 \\
19 & $53.609^{\prime}$ & $45.201^{\prime}$ & 35 & 4 & 12 & 6 & 9 & 15 & 6 & 81 & Low & D7 \\
24 & $54.15^{\prime}$ & $45.343^{\prime}$ & 45 & 4 & 12 & 6 & 10 & 15 & 12 & 92 & Low & D8 \\
36 & $52.2^{\prime}$ & $44.901^{\prime}$ & 45 & 4 & 12 & 4 & 10 & 15 & 6 & 90 & Low & D9 \\
26 & $54.82^{\prime}$ & $45.901^{\prime}$ & 45 & 4 & 12 & 6 & 9 & 15 & 6 & 91 & Low & D10 \\
29 & $55.35^{\prime}$ & $45.75^{\prime}$ & 45 & 4 & 12 & 6 & 9 & 15 & 6 & 91 & Low & D11 \\
35 & $55.604^{\prime}$ & $44.712^{\prime}$ & 45 & 4 & 12 & 10 & 10 & 15 & 6 & 96 & Low & D12 \\
31 & $55.8^{\prime}$ & $43.8^{\prime}$ & 35 & 4 & 12 & 10 & 10 & 15 & 6 & 86 & Low & D13 \\
34 & $54.704^{\prime}$ & $44.303^{\prime}$ & 45 & 4 & 12 & 10 & 10 & 15 & 6 & 96 & Low & D14 \\
40 & $53.653^{\prime}$ & $43.455^{\prime}$ & 45 & 4 & 12 & 10 & 9 & 15 & 6 & 95 & Low & D15 \\
39 & $52.725^{\prime}$ & $43.265^{\prime}$ & 50 & 4 & 12 & 10 & 10 & 15 & 6 & 101 & Low & D16 \\
17 & $53.82^{\prime}$ & $43.8^{\prime}$ & 45 & 4 & 12 & 10 & 9 & 15 & 6 & 95 & Low & D17 \\
14 & $52.85^{\prime}$ & $43.72^{\prime}$ & 35 & 4 & 12 & 10 & 9 & 15 & 6 & 85 & Low & D18 \\
\hline
\end{tabular}

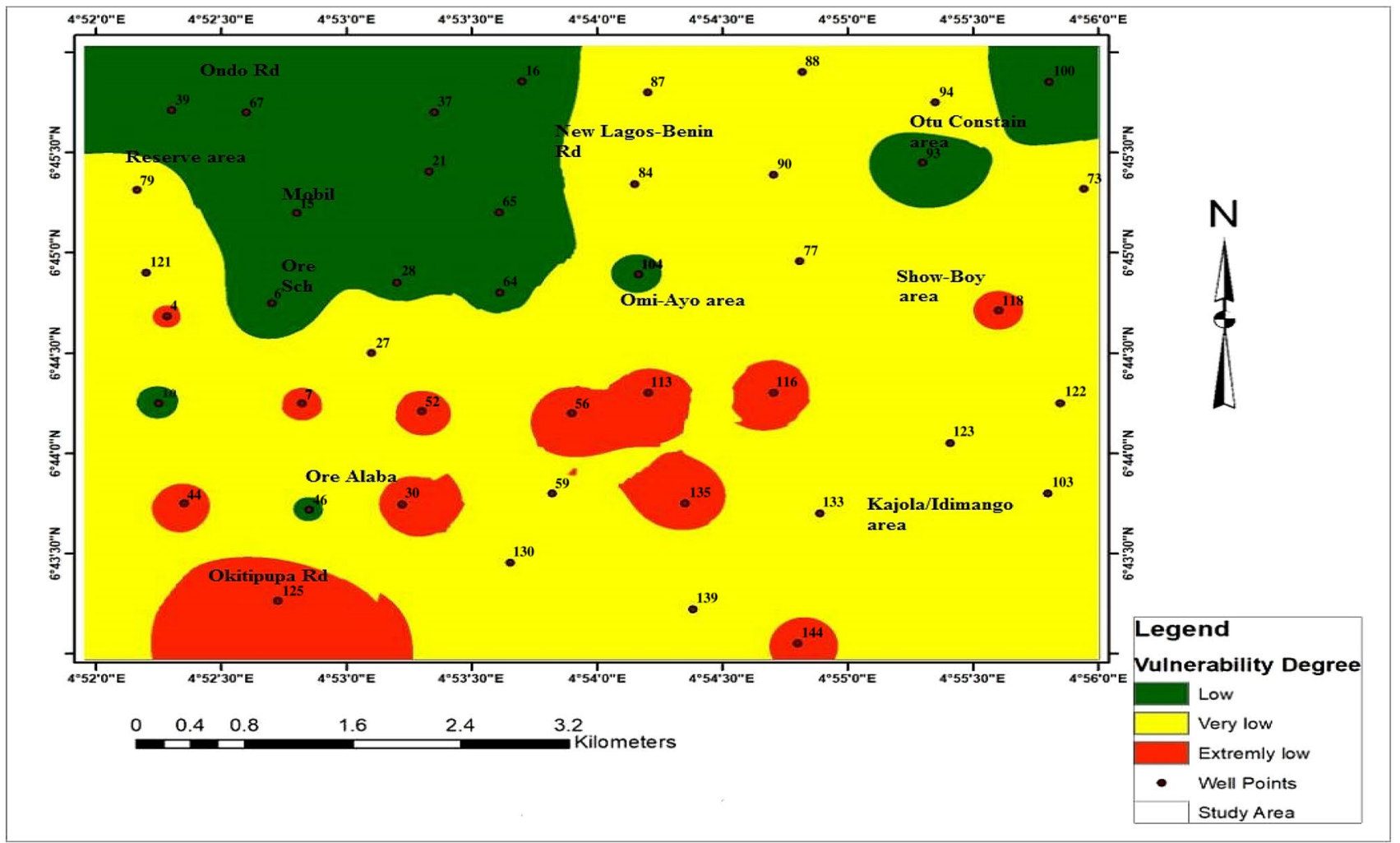

Fig. 5 Groundwater vulnerability map of Ore area 
Table 4 Water quality index characters for Ore area using [17] approach

\begin{tabular}{|c|c|c|c|c|}
\hline Well no & Longitude $004^{\circ} \mathrm{E}$ & Latitude $06^{\circ} \mathrm{N}$ & WQI (index rate) & Type of water \\
\hline 1 & $52.284^{\prime}$ & $44.685^{\prime}$ & 23.36 & Excellent \\
\hline 2 & $52.701^{\prime}$ & $44.7^{\prime}$ & 30.56 & Good \\
\hline 3 & $52.821^{\prime}$ & $44.251^{\prime}$ & 26.06 & Good \\
\hline 4 & $52.25^{\prime}$ & $44.251^{\prime}$ & 24.89 & Excellent \\
\hline 5 & $52.8^{\prime}$ & $45.2^{\prime}$ & 31.79 & Good \\
\hline 6 & $53.701^{\prime}$ & $45.855^{\prime}$ & 11.87 & Excellent \\
\hline 7 & $53.329^{\prime}$ & $45.405^{\prime}$ & 23.23 & Excellent \\
\hline 8 & $53.1^{\prime}$ & $44.501^{\prime}$ & 7.35 & Excellent \\
\hline 9 & $53.201^{\prime}$ & $44.851^{\prime}$ & 16.94 & Excellent \\
\hline 10 & $53.221^{\prime}$ & $43.745^{\prime}$ & 11.91 & Excellent \\
\hline 11 & $53.35^{\prime}$ & $45.7^{\prime}$ & 21.15 & Excellent \\
\hline 12 & $52.301^{\prime}$ & $45.71^{\prime}$ & 19.65 & Excellent \\
\hline 13 & $52.35^{\prime}$ & $43.75^{\prime}$ & 34.20 & Good \\
\hline 14 & $52.85^{\prime}$ & $43.72^{\prime}$ & 37.23 & Good \\
\hline 15 & $53.3^{\prime}$ & $44.21^{\prime}$ & 24.33 & Excellent \\
\hline 16 & $53.9^{\prime}$ & $44.2^{\prime}$ & 38.34 & Good \\
\hline 17 & $53.82^{\prime}$ & $43.8^{\prime}$ & 36.93 & Good \\
\hline 18 & $53.61^{\prime}$ & $44.802^{\prime}$ & 30.49 & Good \\
\hline 19 & $53.609^{\prime}$ & $45.201^{\prime}$ & 24.53 & Excellent \\
\hline 20 & $52.6^{\prime}$ & $45.7^{\prime}$ & 9.05 & Excellent \\
\hline 21 & $55.943^{\prime}$ & $45.319^{\prime}$ & 16.68 & Excellent \\
\hline 22 & $54.809^{\prime}$ & $44.958^{\prime}$ & 17.27 & Excellent \\
\hline 23 & $52.164^{\prime}$ & $45.314^{\prime}$ & 16.42 & Excellent \\
\hline 24 & $54.15^{\prime}$ & $45.343^{\prime}$ & 28.34 & Good \\
\hline 25 & $54.201^{\prime}$ & $45.801^{\prime}$ & 11.68 & Excellent \\
\hline 26 & $54.82^{\prime}$ & $45.901^{\prime}$ & 28.07 & Good \\
\hline 27 & $54.704^{\prime}$ & $45.39^{\prime}$ & 12.29 & Excellent \\
\hline 28 & $55.301^{\prime}$ & $45.45^{\prime}$ & 50.83 & Good \\
\hline 29 & $55.35^{\prime}$ & $45.75^{\prime}$ & 19.27 & Excellent \\
\hline 30 & $55.804^{\prime}$ & $45.852^{\prime}$ & 18.03 & Excellent \\
\hline 31 & $55.8^{\prime}$ & $43.8^{\prime}$ & 15.18 & Excellent \\
\hline 32 & $54.166^{\prime}$ & $44.894^{\prime}$ & 24.58 & Excellent \\
\hline 33 & $54.204^{\prime}$ & $44.301^{\prime}$ & 19.79 & Excellent \\
\hline 34 & $54.704^{\prime}$ & $44.303^{\prime}$ & 22.81 & Excellent \\
\hline 35 & $55.604^{\prime}$ & $44.712^{\prime}$ & 21.84 & Excellent \\
\hline 36 & $52.2^{\prime}$ & $44.901^{\prime}$ & 18.85 & Excellent \\
\hline 37 & $55.85^{\prime}$ & $44.25^{\prime}$ & 24.32 & Excellent \\
\hline 38 & $55.41^{\prime}$ & $44.052^{\prime}$ & 18.97 & Excellent \\
\hline 39 & $52.725^{\prime}$ & $43.265^{\prime}$ & 22.66 & Excellent \\
\hline 40 & $53.653^{\prime}$ & $43.455^{\prime}$ & 20.85 & Excellent \\
\hline 41 & $54.89^{\prime}$ & $43.701^{\prime}$ & 12.97 & Excellent \\
\hline 42 & $54.35^{\prime}$ & $43.75^{\prime}$ & 13.60 & Excellent \\
\hline 43 & $54.382^{\prime}$ & $43.223^{\prime}$ & 17.24 & Excellent \\
\hline 44 & $54.802^{\prime}$ & $43.053^{\prime}$ & 15.66 & Excellent \\
\hline
\end{tabular}


Table 5 Range of water quality indices obtained using [17] approach for drinking purpose

\begin{tabular}{llll}
\hline S/N & Range & Type of water & Ore water \\
\hline 1 & $0-25$ & Excellent/very good & $\begin{array}{c}\text { 68.57\% Fall within the } \\
\text { category } \\
31.43 \% \text { Fall within the } \\
\text { category }\end{array}$ \\
2 & $26-50$ & Good & Nil \\
3 & $51-75$ & Poor & Nil \\
4 & $76-100$ & Very poor & Nil \\
5 & $>100$ & $\begin{array}{l}\text { Unsuitable for drink- } \\
\text { ing purpose }\end{array}$ \\
\hline
\end{tabular}

Table 6 DRASTIC index range for qualitative category used approach according to [18]

\begin{tabular}{ll}
\hline DRASTIC qualitative category (QRC) & $\begin{array}{l}\text { Range of } \\
\text { DRASTIC index } \\
\text { (DI) }\end{array}$ \\
\hline Low & $0-120$ \\
Moderate & $120-140$ \\
High & $140-200$ \\
Very high & $>200$ \\
\hline
\end{tabular}

assigned to measured parameters based on their relative importance in water quality and possible health effects. The maximum weight of 5 is assigned to parameters like sodium, chloride, TDS and sulfate because of their importance in water quality assessments. A less weight of 1 is given to bicarbonate since it plays a comparatively less significant role in water quality assessment [17].

In the second step, relative weights $\left(\mathrm{R}_{\mathrm{wi}}\right)$ are calculated using Equation ( $v$ ).

$\mathrm{R}_{w i}=\mathrm{A}_{w i} / \sum_{i}^{n} \mathrm{~A} w i$

where $R_{w i}$ relative weight, $A_{w i}$ assigned weight of each parameter and $n$ number of parameters.

In the third step, a quality rating (qi) for each parameter is calculated by dividing their concentration with respective water quality standard according to the guidelines laid down in the WHO (2011), and this value is multiplied with 100 as shown in the equation below.

$q i=(C i / S i) \times 100$

where $q i$ is quality rating, $C i$ is concentration of each chemical parameter of water samples taken in $\mathrm{mg} / \mathrm{l}$. and $\mathrm{Si}$ is WHO drinking water standard for each chemical parameter in milligrams per liter according to the guidelines of the [17].

For computing the WQI, the sub index (Sli) for each chemical parameter is determined and WQI is calculated using Eq. (8) and the final WQI for the each sample is determined as explained in Eq. (9).
Table 7 Ranges and ratings for depth to water table, net recharge, topography and hydraulic conductivity [3]

Table 8 Ranges and ratings for aquifer media, soil media and impact of vadose zone [3]

\begin{tabular}{|c|c|c|c|c|c|c|c|}
\hline \multirow{2}{*}{\multicolumn{2}{|c|}{$\frac{\text { Depth to water table }}{\text { Range (ft) rating }}$}} & \multirow{2}{*}{\multicolumn{2}{|c|}{$\frac{\text { Net recharge }}{\text { Range (inches) rating }}$}} & \multirow{2}{*}{\multicolumn{2}{|c|}{$\frac{\text { Topography }}{\text { Range (\%slope) rating }}$}} & \multirow{2}{*}{\multicolumn{2}{|c|}{$\begin{array}{l}\text { Hydraulic conductivity } \\
\text { Range(gpd/ft) rating }\end{array}$}} \\
\hline & & & & & & & \\
\hline $0-5$ & 10 & $0-2$ & 1 & $0-2$ & 10 & $1-100$ & 1 \\
\hline $5-15$ & 9 & $2-4$ & 3 & $2-6$ & 9 & $100-300$ & 2 \\
\hline 15-30 & 7 & $4-7$ & 6 & $6-12$ & 5 & $300-700$ & 4 \\
\hline $30-50$ & 5 & $7-10$ & 8 & $12-18$ & 3 & $700-1000$ & 6 \\
\hline 50-75 & 3 & $>10$ & 9 & $>18$ & 1 & $1000-2000$ & 8 \\
\hline 75-100 & 2 & & & & & $>2000$ & 10 \\
\hline$>100$ & 1 & & & & & & \\
\hline
\end{tabular}

\begin{tabular}{|c|c|c|c|c|c|}
\hline \multicolumn{2}{|l|}{ Aquifer media } & \multicolumn{2}{|l|}{ Soil media } & \multicolumn{2}{|c|}{ Impact of vadose zone } \\
\hline Type & Rating & Range & Rating & Range & Rating \\
\hline Massive shale & 2 & Clay & 1 & Fresh rock & 1 \\
\hline Metamorphic/igneous & 3 & Clay & 2 & Sand, silt and clay & 3 \\
\hline Weathered metamorphic/Igneous & 4 & Clay loam & 3 & Metamorphic rock & 4 \\
\hline Bedded sandstone/limestone/shale & 5 & Silty loam & 4 & Sand and gravel & 6 \\
\hline Massive sandstone & 6 & Sandy loam & 5 & Limestone & 6 \\
\hline Massive limestone & 6 & Peat & 8 & Boulders/rubbles & 9 \\
\hline Sand and gravel & 8 & Sand & 9 & & \\
\hline Basalt & 9 & Gravel & 10 & & \\
\hline Karst limestone & 10 & Thin/absent & 10 & & \\
\hline
\end{tabular}


$\mathrm{Sl} i=\mathrm{Rw} i \times q i$

$\mathrm{WQI}=\Sigma \mathrm{Sli}$

where $S l i$ is subindex of $i$ th parameter, $q i$ is rating based on concentration of $i$ th parameter and $\mathrm{n}$ is the number of parameters.

The indices obtained for the groundwater samples are presented on Table 4. Their ranges are classified on Table 5. About $69 \%$ of the samples fall within the excellent/very good category, while the remaining $31 \%$ fall within the good category (Table 6).

\subsection{DRASTIC approach}

Wells around each recharge and discharge areas were assessed for pollution potentials using the DRASTIC approach. The results show that weight value for depth to water table ranges from 35 to 45 . According to [3], depth to water table has been assigned the highest weighable value of 5 (Table 7) and most of the wells falls within the rating of 7 and 9 . For the net recharge, the weight value is 4 for all the locations. The aquifer media for Ore are the unconfined aquifer produced from the weathering of the underlying basement rocks. Hence, the aquifer media are classified as weathered metamorphic/igneous aquifer system and assigned a weight of 3 and rating of 4 (Table 8). The weight value for the aquifer media is $12 \mathrm{for}$ all locations. Furthermore, the soil types identified within the area are clay, silty clay and sandy clay. The sandy soil media were assigned with maximum rating value of 5 , the silty clay media were assigned rating of 3 , and the clay soil media were assigned with minimum rating of 2 [3] (Table 8). The weight value for soil media ranges between 4, 6 and 10, respectively. The DRASTIC topography in the study area has a weight value ranging from 9 to 10 . The impact of vadose zone has a weight of 5 [3]. The most significant part of the area included sand, silt and clay with assigned rating of 3 [3] (Table 8). The weight value for the impact of vadose zone is 15 for all the locations within the study area. The hydraulic conductivity has a weight of 3, and rating was between 2 and 4 with the major part of the area having low hydraulic conductivity. The weight value for hydraulic conductivity ranges between 6 and 12 , respectively.

The DRASTIC index was obtained for each of the wells in each recharge area. The indices were summed up for all the recharge areas (R1-R12). The same thing was done for the discharge areas (D1-D18). The drastic index (DI) for the area is between 79 and 101. The results showed that both the recharge areas and discharge areas have low DRASTIC index values. This indicates that based on the prevailing conditions, groundwater sourced from both the recharge and discharge areas is less pollution-prone.

\section{Conclusion}

The chemical quality of groundwater samples is within the acceptable limits of the World Health Organization (WHO) standards for drinking, domestic and irrigation purposes in the study area. The $\mathrm{Ca}-\mathrm{HCO}_{3}$ hydrochemical facies type dominates the association of ions present in the samples. The results showed that both the recharge areas and discharge areas have low DRASTIC index values. Groundwater sourced from both recharge and discharge areas is generally less prone to pollution. The distributions of both areas are anthropogenically controlled. The water quality indices for the study area fall within good to excellent/very good categories.

\section{Compliance of ethical standards}

Conflict of interest The authors declare no conflict of interest in this study.

\section{References}

1. Acworth RI (1987) The development of crystalline basement aquifers in tropical environments. Q J Eng Geol Lond 20:265-272

2. Ahirwar S, Shukla JP (2018) Assessment of groundwater vulnerability in Upper Betwa River watershed using GIS-based DRASTIC model. J Geol Sci India 91:334

3. Aller L, Bennet T, Lehr JH, Petty RJ, Hackett G (1987) DRASTIC: a standardized system for evaluating ground water pollution potential using hydrogeologic settings. US EPA report 600/2$87 / 035$, U.S. Environmental Protection Agency. Retrieved on July 14, 2009, from http://www.epa.gov/nscep

4. Al-Hanbali A, Kondoh A (2008) Groundwater vulnerability assessment and evaluation of human activity impact (HAI) within the Dead Sea groundwater basin, Jordan. Hydrogeol J $16: 499-510$

5. Al-Mallah IAR, AI-Qurnawi WS (2018) Intrinsic vulnerability for the quatenary aquifer in bashdad area using DRASTIC model. Appl Water Sci 8:139

6. Agyare A, Anormu GK, Kabo-bah AT (2017) Assessing the vulnerability of aquifer systems in the Volta River Basin: a case study on Afram plains, Ghana. Model Earth Syst Environ 3:1141-1159

7. Faniran A (1970) Landform examples from Nigeria No. 2 The deep weathering (Duricrust) profile. Niger Geogr J 13:87-88

8. Freeze RA, Cherry JA (1979) Groundwater. Prentice Hall, Eaglewood Cliffs

9. Krishna Rao (1970): Assessment of Ground Water Potential. All India Seminar on small watershed development, organized by Indian Association of Hydrologists, West Bengal Center, Calcutta (1996)

10. Liggett JE, Talwar S (2009) Groundwater vulnerability assessments and integrated water resources management. Watershed Manag Bull 13(1):18-29 
11. National Population Commission (NPC) (2006) National Population Census. Federal Republic of Nigeria Official Gazette 96(2)

12. Nickson RT, McArthur JM, Shresthn B, Kyaw- Nyint TO, Lowry D (2005) Arsenic and other drinking water quality issues, Muzaffargarh District, Pakistan. Appl Geochem 20(1):55-66

13. Olabode OF (2019) Potential groundwater recharge sites mapping in a typical basement terrain: a GIS methodology approach. J Geovis Spat Anal 3:5

14. Ondo State Ministry of Economic Planning and Budget (2010) The publication of facts and figures of Ondo State of Nigeria. Research and Statistics Dept. 7-9

15. Ondo State Ministry of Lands, Housing and Environment (2000) Ecological report and engineering design for flood and erosion control works in Idanre township. MLHE, Akure

16. Owoseni JO, Komolafe AA (2014) The role of groundwater vulnerability in land use and urban development planning. FUTA SET BoR Chap 51 (ISBN-978-978-942-144-2)
17. Rahaman MA (1976) Review of the basement geology of the southwestern Nigeria. In: Kogbe CA (ed) Geology of Nigeria. Elizabethan Publishing Co., Lagos, pp 4-58

18. Vasanthavigar M, Srinivasamoorthy K, Vijayaragavan K, Ganthi RR, Chidambaram S, Anandhan P, Manivannan R, Vasudevan S (2010) Application of water quality index for groundwater quality assessment: thirumanimuttar sub-basin, Tamilnadu, India. Environ Monit Assess 171:595-609

19. WHO (2011) Guidelines for drinking-water quality, 4th edn. WHO Press, Geneva, p 541

20. Wu X, Li B, Ma C (2018) Assessment of groundwater vulnerability by applying the modified DRASTIC model in Beinai City, China. Environ Sci Pollut Resc 25:12713

Publisher's Note Springer Nature remains neutral with regard to jurisdictional claims in published maps and institutional affiliations. 